\title{
Analysis of mouse uterine proteins at pro-oestrus, during early pregnancy and after administration of exogenous steroids
}

\author{
S. B. Fishel \\ Marshall Laboratory, Physiological Laboratory, University of Cambridge, \\ Cambridge CB2 3EG, U.K.
}

\begin{abstract}
Summary. Uterine secretions were analysed after labelling with $\mathrm{L}-\left[4,5-{ }^{3} \mathrm{H}\right]$ leucine. During pro-oestrus major protein peaks were seen with approximate mol. wt $2.0 \times 10^{4}, 2.7 \times 10^{4}, 4.0 \times 10^{4}, 5.7 \times 10^{4}, 7.8 \times 10^{4}$ and $13.0 \times 10^{4}$. Qualitative changes were observed during the first 4 days of pregnancy. On day 4 p.c. secretions revealed two prominent peaks with mol. wt $6.7 \times 10^{4}$ and $12.5 \times 10^{4}$, four peaks between 2.0 and $4.7 \times 10^{4}$ and one at $8.5 \times 10^{4}$ and one at $20.0 \times 10^{4}$. Profiles similar to those on Day 4 p.c., and implantation, were induced in ovariectomized females by administration of exogenous progesterone and oestradiol, whereas the proteins detected after administration of exogenous oestradiol alone were essentially similar to those found at pro-oestrus. Ovariectomized mice treated with the steroid sequence to mimic Day 4 p.c. profiles but not given the final injection of oestradiol showed no detectable labelled proteins. Injection of progesterone or oestradiol alone, in the final sequence of injections given to ovariectomized pregnant females treated with progesterone, did not induce blastocyst implantation. These studies indicate a synergistic relationship between progesterone and oestrogen in the secretion of uterine macromolecules.
\end{abstract}

\section{Introduction}

Implantation of the embryo in rats and mice is dependent on the secretion of a precise sequence of ovarian steroids (Psychoyos, 1969; McLaren, 1973; Surani, 1975). These steroids regulate the growth of uterine tissue (Tachi, Tachi \& Lindner, 1972; Hsueh, Peck \& Clark, 1975; O'Grady \& Bell, 1977), thereby sensitizing the uterus for implantation (Psychoyos, 1973), and also induce characteristic changes in the protein content of the uterine lumen (Surani, 1975, 1977a; Gore-Langton \& Surani, 1976; Aitken, 1977; Pratt, 1977). To study these changes experimentally implantation is prevented by ovariectomy of pregnant females, the delay is maintained by treatment with exogenous progesterone (Cochrane \& Meyer, 1957), and implantation is induced by injection of oestrogen with progesterone (Psychoyos, 1969).

Before implantation, which is initiated at about 93 h p.c. in the mouse (Finn \& McLaren, 1967), the blastocyst becomes responsive to changes in its environment (Fishel \& Surani, 1978) and embryonic metabolism is greatly increased (Woodland \& Graham, 1969; Weitlauf, 1971; McLaren, 1973). However, if mice are ovariectomized on Day 2 p.c. and maintained on progesterone (Yoshinaga \& Adams, 1966) the protein content of the uterus is reduced (Aitken, 1977), the embryos enter a stage of diapause and implantation is delayed. Hence embryonic response and subsequent implantation may be modulated by the presence of certain macromolecules in the uterine secretions (Webb \& Surani, 1975; Surani, 1977b, c).

The purpose of this study was to analyse the secretion of proteins of the mouse during prooestrus and the first 4 days of pregnancy and after exogenous steroid administration to spayed females. 


\section{Materials and General Methods}

\section{Animals}

The CFLP female mice (Anglia Laboratories) were aged between 6 and 10 weeks and were kept under standard animal house conditions and on a lighting schedule of 05:00 h-19:00 h. CFLP males, aged approximately 3 months, were used for mating. Day 1 was the day of finding a vaginal plug.

\section{Materials}

Progesterone (4-pregnene-3,20-dione) and oestradiol benzoate (1,2,5(10)-oestratriene-3,13diol-3-benzoate) were obtained from Koch-Light Laboratories. L- $\left[4,5-{ }^{3} \mathrm{H}\right]$ leucine (sp. act. 53 $\mathrm{Ci} / \mathrm{mmol}$; Radiochemical Centre, Amersham) was used in all protein studies. Tribromoethyl alcohol with amylene hydrate (Avertin: Winthrop Laboratories) was used as an anaesthetic.

\section{Radioactive labelling of proteins}

Each animal was anaesthetized by an i.p. injection of tribromoethyl alcohol with amylene hydrate using $0.2 \mathrm{ml}$ of a $1.2 \%$ solution per $\mathrm{g}$ body weight. A mid-ventral incision was made and the cervical end of the uterus was ligated. The pro-oestrous females and the ovariectomized animals used after 4 days of oestradiol injections had accumulated between 70 and $150 \mu 1$ fluid, which was aspirated before injection of the radioactive precursor. The precursor used was L-[4,5${ }^{3} \mathrm{H}$ leucine made up as $10 \mu \mathrm{Ci} / \mu \mathrm{l} 0.9 \% \mathrm{NaCl}$ and injected intraluminally with a $100 \mu \mathrm{l}$ Hamilton syringe (Hamilton Bonaduz, Switzerland). The needle was held in the uterus at the utero-tubal end for $30 \mathrm{sec}$ after the injection before removal and cauterization of the injection site. The animals were sutured with Michel's $7.5 \mathrm{~mm}$ suture clips (Holborn Surgical Instruments, London) and recovered within 90 min after the operation.

\section{Collection of samples}

The animals were killed by cervical dislocation $6 \mathrm{~h}$ after the injection of radioactive leucine. The uterine horns were dissected out and placed on filter paper which was soaked with cold $0 \cdot 01$ $\mathrm{M}$ phosphate-buffered saline (PBS) at $\mathrm{pH} \mathrm{7.2.} \mathrm{Connective} \mathrm{tissue} \mathrm{was} \mathrm{trimmed} \mathrm{away} \mathrm{and} \mathrm{the}$ horns were gently rolled on the filter paper to remove any traces of blood. Each horn was flushed from the oviductal end with $0.05 \mathrm{ml} 0.01 \mathrm{M}$-PBS, $\mathrm{pH} 7 \cdot 2$. The samples were immediately centrifuged at $12000 \mathrm{~g}$ at $0^{\circ} \mathrm{C}$ for $1 \mathrm{~h}$ and the supernatant was aspirated. To each aspirate $10 \mu \mathrm{l}$ of a buffer concentrate was added to give a final concentration of $0.1 \%$ sodium dodecyl sulphate (SDS), 0.14 M-2-mercaptoethanol, $0.002 \%$ bromophenol blue and $10 \%$ glycerol. Some samples, immediately after aspiration, were stored at $-20^{\circ} \mathrm{C}$ for up to 14 days before use and others were used immediately; no differences in the results were detected. After addition of buffer concentrate, samples were heated at $65^{\circ} \mathrm{C}$ for $1 \mathrm{~h}$ to form protein-SDS complexes.

\section{Analysis of uterine secretions}

Uterine secretions were analysed by electrophoresis on $6 \%$ polyacrylamide disc-gels according to the method described by Surani (1977a). The gel columns of $7.5 \mathrm{~cm}$ expanded to approximately $8.0 \mathrm{~cm}$. Each gel was rinsed twice with distilled water, dried on tissue paper, placed on a metal plate and covered with finely ground solid $\mathrm{CO}_{2}$. The gel was frozen solid within $15 \mathrm{~min}$ and sliced into approximately 80 discs, each $1 \mathrm{~mm}$ thick, using a gel slicer consisting of a series of razor blades mounted on two parallel brass rods $1 \mathrm{~mm}$ apart. Each disc 
was placed in a flat-bottomed glass tube $(5 \mathrm{~cm} \times 1.1 \mathrm{~cm}$ ) with $0.2 \mathrm{ml}$ Soluene-350 (Packard: Downers Grove, Illinois, U.S.A.). The tubes were sealed and left over night at $60^{\circ} \mathrm{C}$. The $4.0 \mathrm{ml}$ scintillation fluid, consisting of $5.5 \mathrm{~g}$ Permablend III (Permablend III contains $91 \%$ PPO and $9 \%$ bis-MSB: Packard)/1 toluene, were added and the tubes were placed in a scintillation vial and left in the dark for another night before being counted in a scintillation spectrophotometer (Tracerlab: Packard). The efficiency of counting for tritium was $38 \%$. Before the samples were analysed an aliquot was removed and precipitable counts were determined; the samples analysed contained between 12.3 and $26.4 \times 10^{-3}{ }^{3} \mathrm{H}$ d.p.m.

\section{Detailed Methods and Results}

\section{Controls}

The uterocervical junction was ligated in 8 pro-oestrous and 9 Day-4 p.c. females. Four (4) of the pro-oestrous and 3 of the Day-4 p.c. females were injected with $10 \mu l 0.9 \%(\mathrm{w} / \mathrm{v}) \mathrm{NaCl}$ solution into each horn, and immediately afterwards each received a single i.p. injection of 30 $\mu \mathrm{Ci}\left[{ }^{3} \mathrm{H}\right]$ leucine in $0.3 \mathrm{ml} 0.9 \% \mathrm{NaCl}$. The other animals were given an intraluminal injection of $10 \mu \mathrm{Ci}\left[{ }^{3} \mathrm{H}\right]$ leucine into the right horn and $10 \mu \mathrm{l} 0.9 \%$ saline into the left horn.

Intraperitoneal injection of the $\left[{ }^{3} \mathrm{H}\right]$ leucine did not result in the appearance of any radioactive proteins on the polyacrylamide gels. Protein profiles containing radioactivity were found only in the samples from the uterine horns which had directly received the radioactive precursor.

Representative results of reproducible profiles (profile/animal) obtained from the electrophoretic and spectrophotometric analyses of the uterine proteins of the experimental mice are shown in Text-figs 1-4.

\section{Uterine proteins at pro-oestrus and Days $1-4$ p.c.}

Intraluminal injection of radioactive precursor was given to 9 pro-oestrous mice, 8 mice on each of Days 1, 2 and 3 p.c. and 11 mice on Day 4 p.c. at 14:00 h and left for $6 \mathrm{~h}$ before the luminal proteins were analysed as described above.

The profiles during pro-oestrus (Text-fig. 1a) consisted of 6 major detectable protein peaks with molecular weights of approximately $2.0 \times 10^{4}, 2.7 \times 10^{4}, 4.0 \times 10^{4}, 5.7 \times 10^{4}, 7.8 \times 10^{4}$ and $13.0 \times 10^{4}$. On Day 1 (Text-fig. 1b) 4 major peaks were observed with molecular weights around 7.5 and $8.4 \times 10^{4}$ and at 22.0 and $25.0 \times 10^{4}$. The bulk of radioactivity was incorporated into protein of the highest molecular weight. Minor protein peaks were evident at $14.0 \times 10^{4}$ and $17.5 \times 10^{4}$. On Day 2 p.c. (Text-fig. 1c) 6 proteins were detected but the bulk of radioactivity had shifted from the higher molecular weight protein of Day 1 to a range of proteins in the region of $7.5 \times 10^{4}$ to $12.0 \times 10^{4}$. The detectable proteins had approximate molecular weights of $4.5 \times 10^{4}, 7.5 \times 10^{4}, 9.3 \times 10^{4}, 12.0 \times 10^{4}, 15.5 \times 10^{4}$ and $22.0 \times 10^{4}$. Comparatively less radioactivity was incorporated into uterine secretions on Day 3 p.c. (Text-fig. 1d). There were 4 minor peaks detectable at molecular weights corresponding to $3.6 \times 10^{4}, 4.3$ $\times 10^{4}, 6.6 \times 10^{4}$ and $22.0 \times 10^{4}$. On Day 4 (Text-fig. 1e) 8 peaks were detectable: 2 predominated at molecular weights $6.7 \times 10^{4}$ and $12.5 \times 10^{4}$, the others occurring at $2.0 \times 10^{4}$, $2.6 \times 10^{4}, 2.9 \times 10^{4}, 4.7 \times 10^{4}, 8.5 \times 10^{4}$ and $20.0 \times 10^{4}$.

Only approximate molecular weights can be determined hence the value of the information obtained is in comparative results. Most of the proteins detected from pro-oestrus to Day 4 p.c. were not found only at specific stages. However, unique peaks occurred with corresponding molecular weights of $5.7 \times 10^{4}$ at pro-oestrus; $14.0 \times 10^{4}, 17.5 \times 10^{4}$ and $25.0 \times 10^{4}$ on Day 1 p.c. and $9.3 \times 10^{4}$ and $15.5 \times 10^{4}$ on Day 2 p.c. On Day 4 p.c. proteins detected in the $2.0-4.7$ $\times 10^{4}$ region were observed in all but Day 1 of the previous stages, the two major peaks at 6.7 


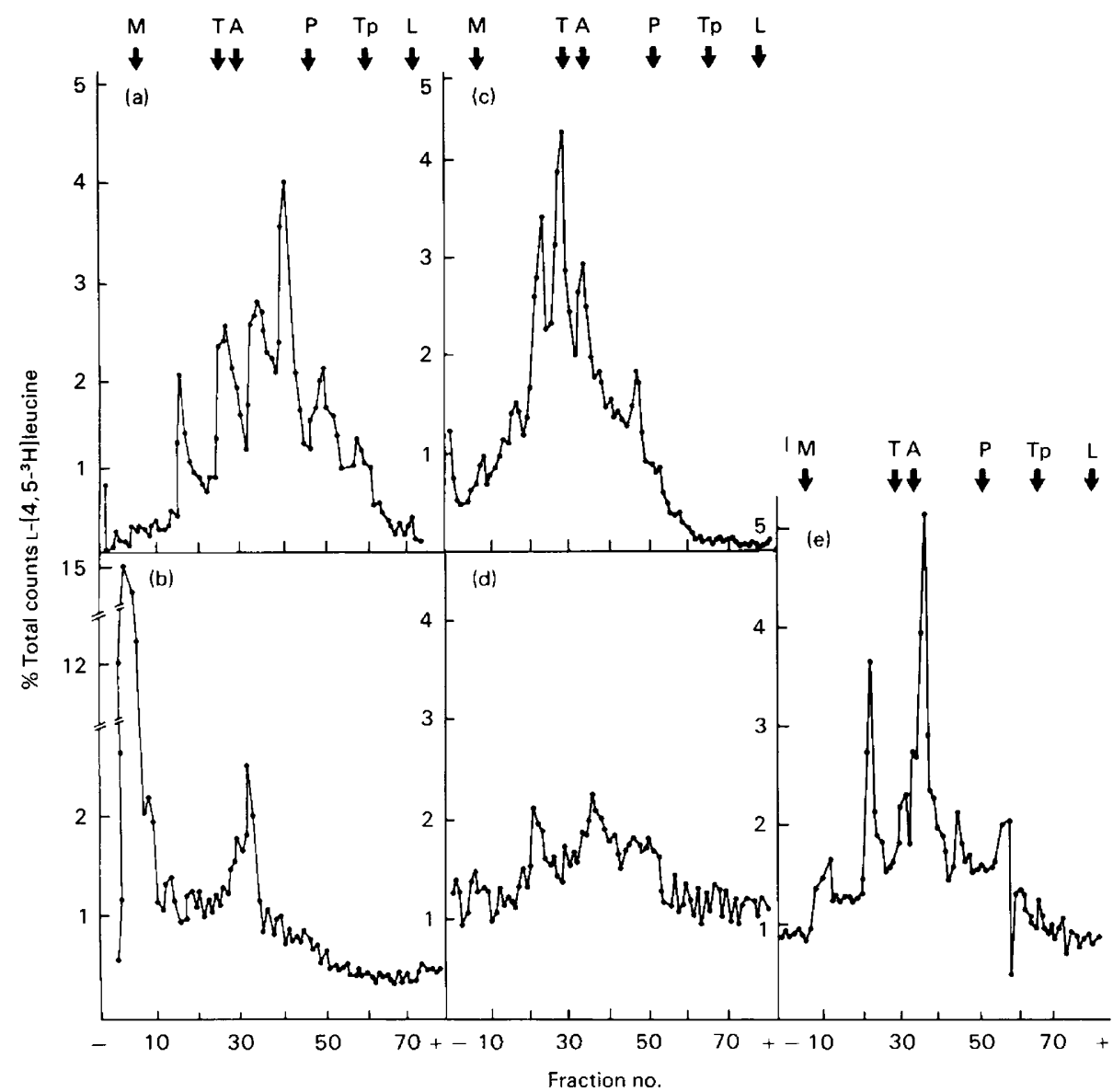

Text-fig. 1. Radioactive counts, as a \% of total counts, of $\left[{ }^{3} \mathrm{H}\right]$ leucine-labelled uterine-specific proteins in uterine fluid samples from mice at (a) pro-oestrus and (b) Day 1, (c) Day 2, (d) Day 3 and (e) Day 4 post coitum. Each fraction represents $1 \mathrm{~mm}$ of a $6 \%$ polyacrylamide gel. The positions of substances of known molecular weight are indicated at the top of the figure: $\mathbf{M}=$ myosin, mol. wt $220000 ; \mathrm{T}=$ transferrin, mol. wt $82000 ; \mathrm{A}=$ bovine serum albumin, mol. wt $66500 ; \mathrm{P}=$ peroxidase, mol. wt $40000 ; \mathrm{Tp}=$ trypsin, mol. wt $23300 ; \mathrm{L}=$ lysozyme, mol. wt 14300 .

and $12.5 \times 10^{4}$ were also detected on Day 3 and the protein $8.5 \times 10^{4}$ was detected on Day 1 . The highest molecular weight protein, $20.0 \times 10^{4}$, also appearing on Day 4 , was detected at all stages of pregnancy. Proteins with molecular weights between 7.5 and $7.8 \times 10^{4}$ were detected at pro-oestrus, Day 1 and Day 2 p.c. only.

\section{Effects of progesterone and oestradiol on the appearance of uterine proteins}

A group of 18 ovariectomized mice was given a single s.c. injection of $1.0 \mathrm{mg}$ progesterone + $20 \mathrm{ng}$ oestradiol benzoate in $0.1 \mathrm{ml}$ arachis oil. Daily injections of $1.0 \mathrm{mg}$ progesterone in 0.1 $\mathrm{mg}$ arachis oil were then given for 10 days. On Day 11 an injection of $1.0 \mathrm{mg}$ progesterone and $20 \mathrm{ng}$ oestradiol in $0.1 \mathrm{ml}$ arachis oil was given to each female. The animals were injected intraluminally with labelled precursor at 0 (4 mice), 6 (4 mice), 12 (6 mice) and 18 (4 mice) h after the last injection and were killed $6 \mathrm{~h}$ after the intraluminal injection for examination of the time of appearance of labelled proteins in the uterine fluid. 


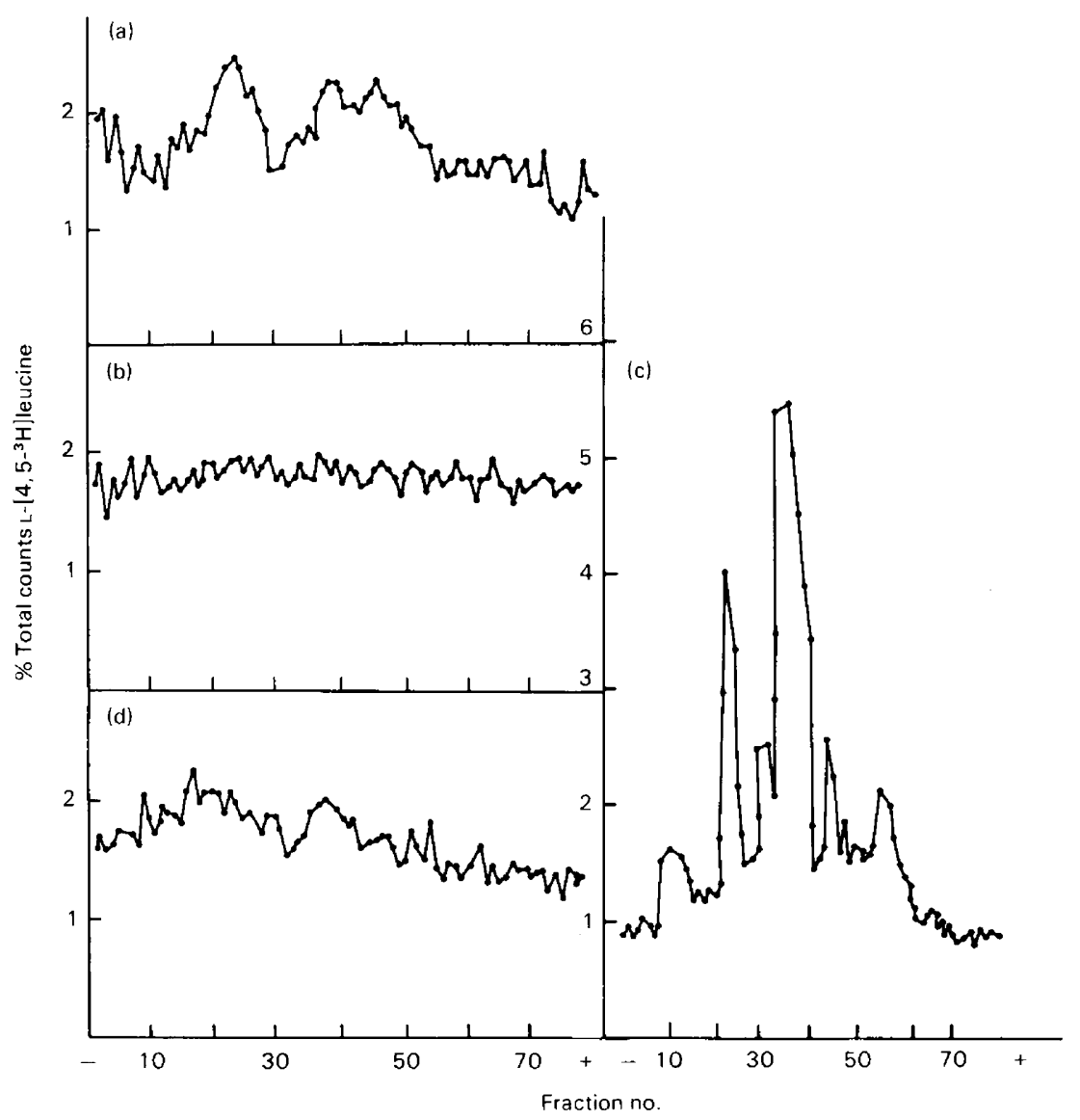

Text-fig. 2. The appearance of $\left[{ }^{3} \mathrm{H}\right]$ leucine-labelled uterine-specific proteins after injection of oestradiol and progesterone to ovariectomized mice: (a) 0-6 h, (b) 6-12 h, (c) 12-18 h, (d) 18$24 \mathrm{~h}$.

The results obtained are shown in Text-fig. 2. Very few clear protein peaks were detected until $12 \mathrm{~h}$ after injection of progesterone and oestradiol. In the first $6 \mathrm{~h}$ (Text-fig. 2a) minor peaks were detected corresponding to proteins with molecular weights of $4.8 \times 10^{4}, 6.7 \times 10^{4}$ and $12.5 \times 10^{4}$, and at $12-18 \mathrm{~h}$ these proteins and three others $\left(3.1 \times 10^{4}, 8.7 \times 10^{4}\right.$ and $\left.21 \times 10^{4}\right)$ were detected. However, none of these or other proteins were detected during the 6-12 $\mathrm{h}$ labelling period (Text-fig. 2b). The total profile seen 12-18 h after the progesterone and oestradiol injection (Text-fig. 2c) was similar to that found on Day 4 p.c. in naturally mated females, except that the $2.0 \times 10^{4}$ and $2.6 \times 10^{4}$ molecular weight proteins were not detected in the luminal contents of the experimental animals. No major peaks were detected 18-24 h after the injection of exogenous steroids (Text-fig. 2d).

\section{Effects of exogenous oestradiol}

A group of 18 ovariectomized mice was given a single s.c. injection of $20 \mathrm{ng}$ oestradiol in $0 \cdot 1$ $\mathrm{ml}$ arachis oil every $24 \mathrm{~h}$ for up to 5 days (Day 1, 3 mice; Day 2, 3 mice; Day 3, 4 mice; Day 4, 4 mice; Day 5, 4 mice), Day 1 being the day of the first injection, and the radioactive precursor was injected intraluminally $12 \mathrm{~h}$ after the injection of oestradiol. The mice were killed $18 \mathrm{~h}$ after the injection of oestradiol for examination of labelled proteins in the uterine fluid. 


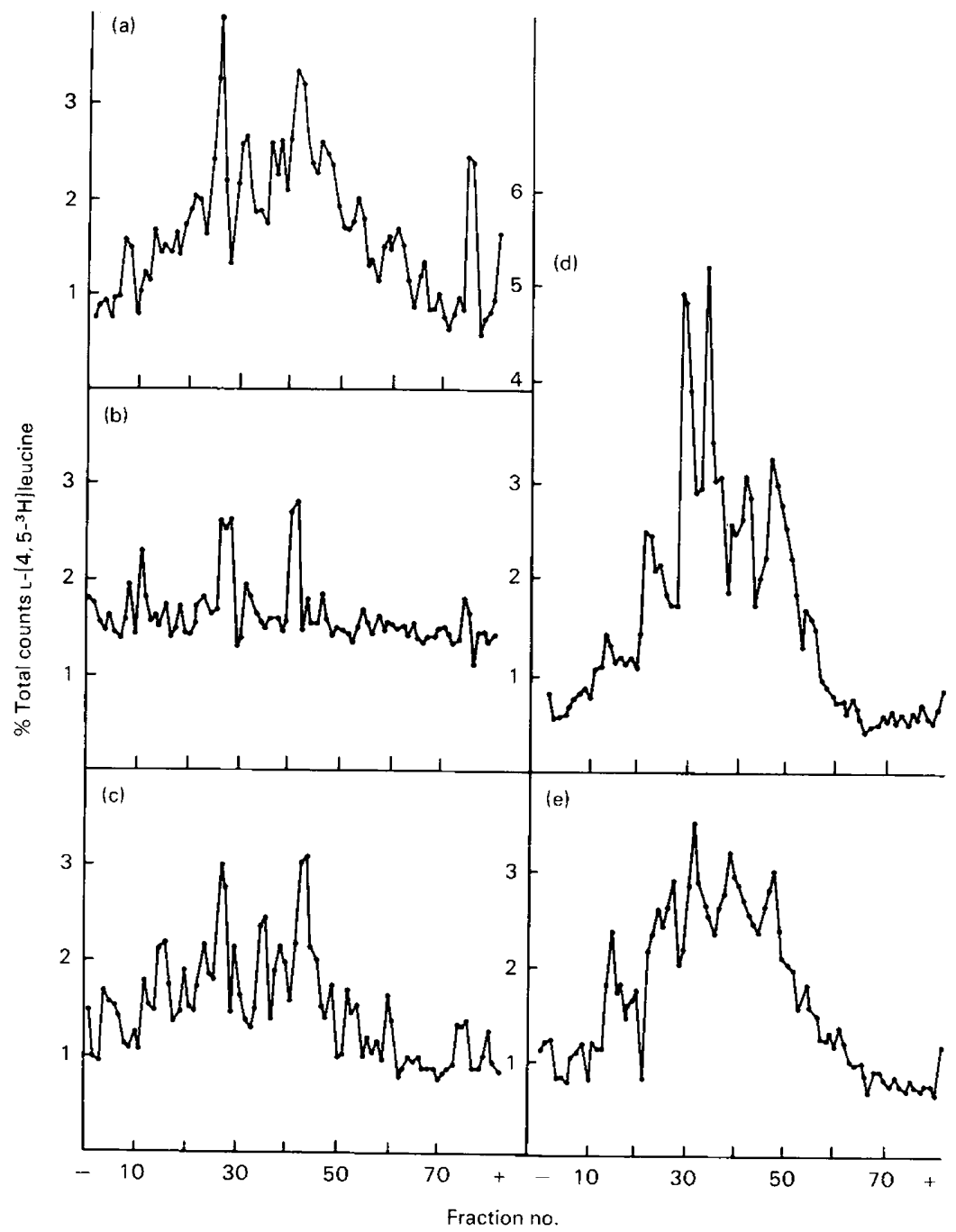

Text-fig. 3. The appearance of $\left[{ }^{3} \mathrm{H}\right]$ leucine-labelled uterine-specific proteins in ovariectomized mice 12-18 h after an injection of oestradiol: (a) 1st injection, (b) 2nd injection, (c) 3rd injection, (d) 4th injection, (e) 5th injection.

As shown in Text-fig. 3 a complex array of labelled proteins was detected in the uterine secretions from each sample. The major proteins detectable after the first injection of oestradiol, Day 1 , were $1.35 \times 10^{4}$ and $10.5 \times 10^{4}$. The major proteins detected on Day 2 were $1.4 \times 10^{4}$, $5.5 \times 10^{4}, 9.8 \times 10^{4}$ and $20.0 \times 10^{4}$. Those on Day 3 had approximate molecular weights of $1.4 \times 10^{4}, 5.2 \times 10^{4}, 7.2 \times 10^{4}$ and $16.5 \times 10^{4}$. However, some of the proteins found at prooestrus (Text-fig. 1a) were detected on Day 4 of the oestradiol treatment schedule, i.e. those of molecular weight $4.2 \times 10^{4}, 5.8 \times 10^{4}$ and $8.0 \times 10^{4}$. Other proteins that were detectable at this stage were $9.9 \times 10^{4}$ and $12.0 \times 10^{4}$ (Text-fig. 3d). After the fifth oestradiol injection, the detectable proteins (Text-fig. 3e) were similar to those found on Day 4 of the sequence and at pro-oestrus, with approximate molecular weights of $3.4 \times 10^{4}, 4.4 \times 10^{4}, 5.7 \times 10^{4}, 8.0 \times 10^{4}$, $10.0 \times 10^{4}, 13.5 \times 10^{4}$ and $19.0 \times 10^{4}$. 


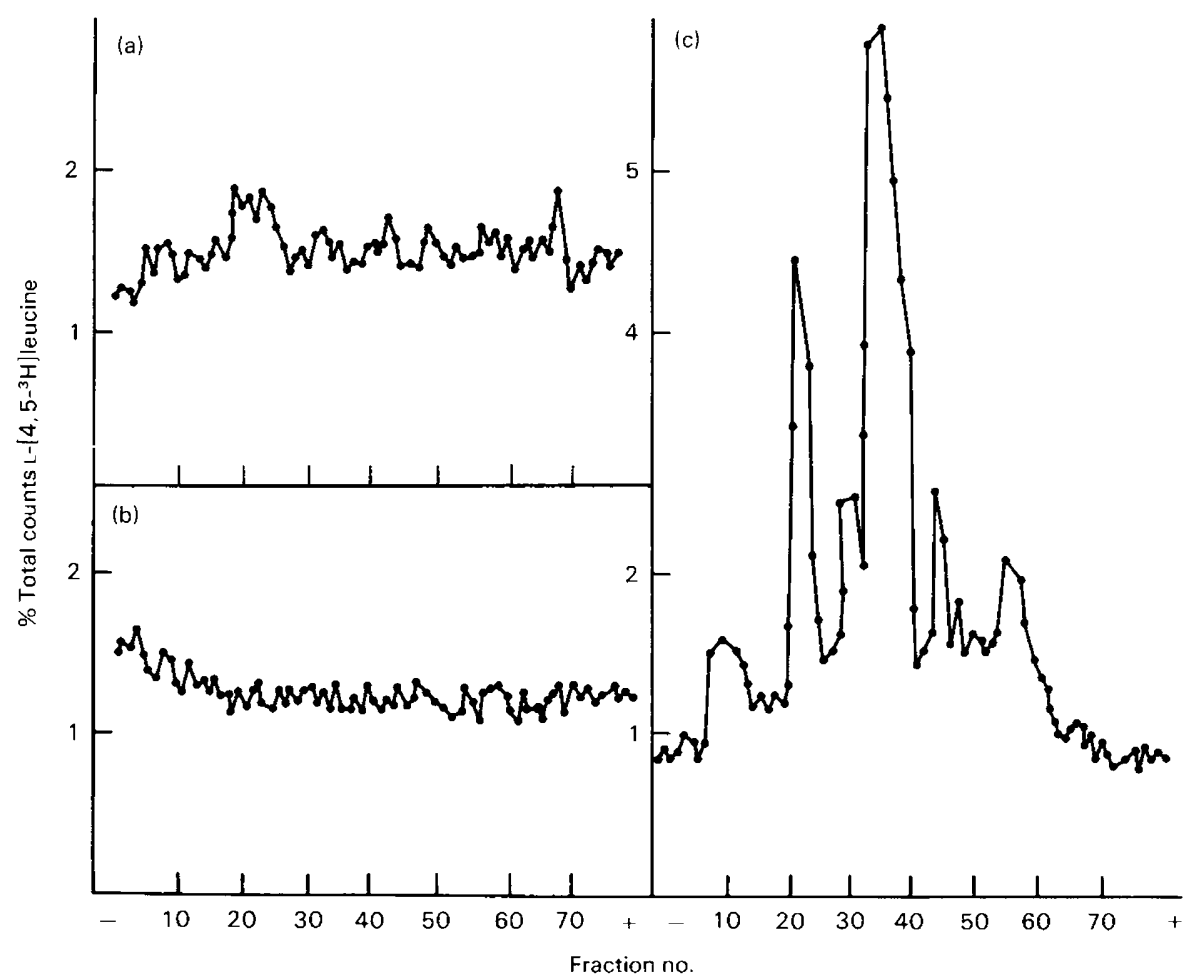

Text-fig. 4. The $\left[{ }^{3} \mathrm{H} \mid\right.$ leucine-labelled uterine-specific proteins detected in the luminal fluid $12-18$ $h$ after an injection of (a) oestradiol, (b) progesterone, (c) oestradiol and progesterone to ovariectomized mice treated with progesterone.

\section{Relationship between hormone sequence for induction of uterine proteins and implantation}

Each of 19 ovariectomized mice was given a single s.c. injection of $1.0 \mathrm{mg}$ progesterone + $20 \mathrm{ng}$ oestradiol in $0.1 \mathrm{ml}$ arachis oil and then given daily s.c. injections of $1.0 \mathrm{mg}$ progesterone in $0.1 \mathrm{ml}$ arachis oil for 10 days. At $12 \mathrm{~h}$ after the last injection 10 of the mice were injected intraluminally with radioactive precursor. The animals were killed $18 \mathrm{~h}$ after the last injection of progesterone for examination of the uterine fluid for labelled proteins. The remaining animals were given a single s.c. injection of $20 \mathrm{ng}$ oestradiol in $0.1 \mathrm{ml}$ arachis oil $24 \mathrm{~h}$ after the last progesterone injection and the labelled precursor was intraluminally injected $12 \mathrm{~h}$ after the oestradiol injection. The animals were killed $6 \mathrm{~h}$ after the injection of precursor for examination of the uterine fluid for labelled protein.

No major protein peaks were detectable when progesterone alone was given (Text-fig. 4b). When animals kept on progesterone were given a final injection of oestradiol without progesterone no major peaks were detected between 12 and $18 \mathrm{~h}$ after injection of the steroid (Text-fig. 4a). Three small peaks corresponding to proteins with molecular weight $13.0 \times 10^{4}$, $11.0 \times 10^{4}$ and $1.5 \times 10^{4}$ were detected. These profiles were compared with those observed when both steroids were given concomitantly (Text-fig. 4c). Little resemblance in macromolecular secretion was observed and experiments were therefore performed to determine if the sequence utilizing oestradiol only in the final injection could support implantation. Mice were ovariectomized on Day 3 p.c. and divided into 3 groups for treatment on Day 4 p.c. The 5 mice in Group A were left untreated for 2 days after ovariectomy then given daily s.c. injections of 1.0 mg progesterone in $0.1 \mathrm{mg}$ arachis oil for 10 days. On the 11th, 12th and 13th day after the 
initial injection of progesterone, a single s.c. injection of $1.0 \mathrm{mg}$ progesterone $+20 \mathrm{ng}$ oestradiol was given and implantation was checked on the 14th day. The 9 mice in Group B were treated as for Group A but on the 11th, 12th and 13th day a single s.c. injection of $20 \mathrm{ng}$ oestradiol was administered. The numbers of implanted embryos were observed on the 14 th day. In Group C ( 5 mice) the cervical end of the utero-cervical junction was ligated at the time of ovariectomy. They were left untreated for 2 days, then treated with daily s.c. injections of $1.0 \mathrm{mg}$ progesterone in $0.1 \mathrm{ml}$ arachis oil for 10 days. On the $11 \mathrm{th}, 12$ th and 13 th day a single s.c. injection of $20 \mathrm{ng}$ oestradiol was given and the number of implantations was observed on the 14th day.

For the 5 animals in Group A 9,2,8,5 and 10 implanted embryos were detected. For the 9 animals in Group B, there were no implanted blastocysts but for 5 of them tested 1, 0,2,1 and 1 blastocysts were found free in the uterine lumen. For the 5 animals in Group C, no implanted blastocysts were found but $10,7,5,8$ and 6 embryos were free in the uterine lumen. However, the traumatic effects of ligation may result in abortive implantations and this was tested.

Mice were mated and then ovariectomized and ligated on Day 3 p.c. Those in Group I ( 5 mice) were left untreated for 2 days and thereafter given a daily s.c. injection of $1.0 \mathrm{mg}$ progesterone in $0.1 \mathrm{ml}$ arachis oil for 10 days. On the $11 \mathrm{th}, 12$ th and 13 th day after the initial progesterone injection, a single s.c. injection of $1.0 \mathrm{mg}$ progesterone $+20 \mathrm{ng}$ oestradiol in $0.1 \mathrm{ml}$ arachis oil was given and the number of implantations was observed at autopsy on Day 14. The 7 mice in Group II were untreated and killed on Day 7 p.c. to check whether implantation had occurred.

For the 5 animals in Group I, 3, 3, 5, 4 and 6 implanted blastocysts were observed, and for the 7 animals in Group II 3, 4, 7, 3, 5, 6 and 1 implanted blastocysts were detected. Therefore the effects of ligation were not responsible for preventing implantation.

\section{Discussion}

The radiolabelled uterine proteins were apparently of uterine origin. The lack of incorporation of radioactivity into the uterine luminal proteins after i.p. injection of the radioactive precursor suggested that little, if any, transudation of radiolabelled serum proteins occurred. Moreover the synthesis of uterine-specific proteins was localized in the horn where the precursor was administered.

The quantitative and qualitative differences in the profiles of samples from mice of Day 4 p.c. and pro-oestrus indicate that there is biochemical response of the uterus to changing ratios of oestradiol and progesterone, although apparent morphological similarities exist with respect to changes of lipid, lysozomes and cellular proliferation (see O'Grady \& Bell, 1977). Previous studies have shown that high levels of oestrogen induce intraluminal secretions in the rat (Armstrong, 1968; Hasegawa, Sugawara \& Takeuchi, 1973; Kennedy, 1974) and the mouse (Aitken, 1977) but high levels of progesterone prevent the accumulation of uterine fluids (Armstrong, 1968; Hasegawa et al., 1973). Quantitative and qualitative changes of protein in the uterine lumen have been monitored in the rat (Surani, 1977a, b) and the mouse (Aitken, 1977; Pratt, 1977).

A protein pattern similar to that at pro-oestrus was found in ovariectomized females treated with oestradiol only. This agrees with results obtained for the rat (Surani, 1977b) which indicate that high oestrogen levels, relative to those found in pregnancy and other stages of the oestrous cycle, are responsible for uterine luminal protein secretion. However, the complete profile of the uterine fluid of the experimental mice was both quantitatively and qualitatively different from that of the normal animals. A close correlation of the profiles between Day 4 p.c. and the experimentally induced Day 4 secretions was obtained. Previous studies (Surani, 1977b) showed a good correlation between the patterns in experimentally induced pro-oestrus and Day-5pregnant rats and the normal state. However the uterine tissue is highly sensitive to changes in the ratios of ovarian steroid hormones, and to induce exact replicates of protein profiles observed 
in normal mice would require more precise hormone administration and stringent temporal conditions in the mouse.

In contrast to previous studies on the mouse (Pratt, 1977), the present studies suggest that most of the uterine-specific proteins are secreted between 12 and $18 \mathrm{~h}$ after the injection of oestradiol and progesterone. These findings agree with other studies for the rat (Surani, 1977b) and the mouse (Aitken, 1977). During the first $6 \mathrm{~h}$ a small amount of radioactivity was detected in three proteins which also occurred in the 12-18 h secretions: two of them, of molecular weight $12.5 \times 10^{4}$ and $6.7 \times 10^{4}$ correspond to those previously observed at $2.5-5 \mathrm{~h}$ (Pratt, 1977). Although detected in small amounts these proteins may play an important role in embryonic metabolism. The fact that they are detected very early and then not again until the 12-18 $\mathrm{h}$ labelling period suggests they may be a product of rapid post-translational modification of stored protein.

The changing profiles observed during the 4 days p.c. were also indicative of the changing ratios of oestrogen and progesterone. The ratio of oestrogen to progesterone falls between prooestrus and Day 3 p.c., and is reflected by the small amount of incorporation into secreted proteins observed on Day 3. The increase in the number of labelled proteins in the lumen on Day 4 p.c. may depict the rise of oestrogen secretion that occurs on Day 4 (McCormack \& Greenwald, 1974), which is probably essential for implantation.

The mode of action of the ovarian steroids in eliciting differing responses is not clear. Their effectiveness may be regulated by the changing hormonal receptor content of the cell (Clark, Anderson \& Peck, 1972; Mester, Martel, Psychoyos \& Baulieu, 1974; Hsueh et al., 1975), as suggested by Surani (1977b), or by specific cell-surface receptors, such as those detected for oestrogen (Pietras \& Szego, 1977). However, the varied endocrinological states of the animal allows for different responses by the uterine tissue to the ovarian steroids (see O'Grady \& Bell, 1977 ) and the subcellular biochemical action of such responses has been discussed (Mangan, 1975).

Ovariectomized mice maintained on progesterone only, after an initial injection of oestradiol and progesterone, showed no detectable radiolabelled proteins $12-18 \mathrm{~h}$ after the final injection of progesterone. These results confirm previous studies on the rat (Surani, 1977b) but are in contrast to recent studies on the mouse (Aitken, 1977). Observations of blastocysts in the uterus of spayed mice maintained on progesterone confirmed earlier work that although the embryos were viable, progesterone could not support implantation (Cochrane \& Meyer, 1959; Psychoyos, 1969). Implantation did not occur in pregnant ovariectomized females maintained on progesterone and given oestradiol $24 \mathrm{~h}$ after the final progesterone injection, and the radiolabelled proteins normally observed at implantation were not detected. These results may indicate the need for uterine-specific proteins in the successful control of implantation in utero and stress the importance of the synergistic regulation that the ovarian steroids impart in eliciting the specific secretion of uterine macromolecules.

I thank Dr M. A. H. Surani for his invaluable advice and expertise. This work was supported by a Medical Research Council Studentship, and supported in part by a Ford Foundation Grant to Professor C. R. Austin and an M.R.C. Project Grant to Dr M. A. H. Surani.

\section{References}

Aitken, R.J. (1977) Changes in the protein content of mouse uterine flushings during normal pregnancy and delayed implantation, and after ovariectomy and oestradiol administration. J. Reprod. Fert. 50, 29-36.

Armstrong, D.T. (1968) Hormonal control of uterine lumen fluid retention in the rat. Am. J. Physiol. 214, 764-771.
Clark, J.M., Anderson, J.N. \& Peck, E.J., Jr (1972) Receptor-estrogen complex in the nuclear fraction of rat uterine cell during the estrous cycle. Science, N.Y. 176, 528-550.

Cochrane, R.L. \& Meyer, R.K. (1957) Delayed nidation in the rat induced by progesterone. Proc. Soc. exp. Biol. Med.96, 155-159. 
Finn, C.A. \& McLaren, A. (1967) A study of the early stages of implantation in mice. J. Reprod. Fert. 13, 259-267.

Fishel, S.B. \& Surani, M.A.H. (1978) Changes in the responsiveness of preimplantation mouse embryos to serum. J. Embryol. exp. Morph. 45, 295-301.

Gore-Langton, R.E. \& Surani, M.A.H. (1976) Uterine luminal proteins of mice. $J$, Reprod. Fert. 46, 271274.

Hasegawa, Y., Sugawara, S. \& Takeuchi, S. (1973) Studies on the uterine fluid of rat. Effects of oestrogen and gestagen on protein content and disc electrophoretic patterns. Jap. J. Anim. Reprod. 19, 73-77.

Hsueh, A.J., Peck, E.J. \& Clark, J.M. (1975) Progesterone antagonism of oestrogen receptors and oestrogen-induced uterine growth. Nature, Lond. 254, 337-339.

Kennedy, T.G. (1974) Effect of relaxin on oestrogeninduced luminal fluid accumulation in the ovariec tomized rat. J. Endocr. 61, 347-353.

Mangan, F. (1975) The biochemical action of steroid hormones at the sub-cellular level. In Biochemistry of Steroid Hormones, pp. 313-337. Ed. H. L. J. Makin. Blackwell Scientific Publications, Oxford.

Martel, D. \& Psychoyos, A. (1978) Progesteroneinduced oestrogen receptors in the rat uterus. $J$. Endocr. 76, 145-154.

McLaren, A. (1973) Blastocyst activation. In The Regulation of Mammalian Reproduction, pp. 321328. Eds S. J. Segal, R. Crozier, P. A. Corfman \& P. G. Condliffe. Charles C. Thomas, Springfield, Illinois.

McCormack, J.T. \& Greenwald, G.S. (1974) Evidence for a preimplantation rise in oestradiol-17ß levels on Day 4 of pregnancy in the mouse. J. Reprod. Fert. 41, 297-301.

Mester, I., Martel, D., Psychoyos, A. \& Baulieu, E.E. (1974) Hormonal control of oestrogen receptor in uterus and receptivity for implantation in the rat. Nature, Lond. 250, 776-778.

O'Grady, J.E. \& Bell, S.C. (1977) The role of the endometrium in blastocyst implantation. In Develop ment in Mammals, Vol. 1, pp. 165-243. Ed. M. H. Johnson. Elsevier/North-Holland Bio-Medical Pess, Amsterdam.
Pietras, R.J. \& Szego, C.M. (1977) Specific binding sites for oestrogen at the outer surfaces of isolated endometrial cells. Nature, Lond. 265, 69-72.

Pratt, H.P.M. (1977) Uterine proteins and the activation of embryos from mice during delayed implantation. J. Reprod. Fert. 50, 1-8.

Psychoyos, A. (1969) Hormonal requirements for egg implantation. $A d v$. Biosci. 4, 275-290.

Psychoyos, A. (1973) Hormonal control of ovoimplantation. Vitams Horm. 31, 201-256.

Surani, M.A.H. (1975) Hormonal regulation of proteins in the uterine secretion of ovariectomized rats and the implications for implantation and embryonic diapause. J. Reprod. Fert. 43, 411-417.

Surani, M.A.H. (1977a) Qualitative and quantitative examination of the proteins of rat uterine luminal fluid during pro-oestrus and pregnancy and comparison with those of serum. J. Reprod. Fert. 50, 281-287.

Surani, M.A.H. (1977b) Radiolabelled rat uterine luminal proteins and their regulation by oestradiol and progesterone. J. Reprod. Fert. 50, 289-296.

Surani, M.A.H. (1977c) Cellular and molecular approaches to blastocyst uterine interactions at implantation. In Development in Mammals, Vol. 1, pp. 245-305. Ed. M. H. Johnson. Elsevier/North Holland, Bio-medical Press, Amsterdam.

Tachi, C., Tachi, S. \& Lindner, H.R. (1972) Modification by progesterone of oestradiol-induced cell proliferation, RNA synthesis and oestradiol distribution in the rat uterus. J. Reprod. Fert. 31, 59-76.

Webb, F.T.G. \& Surani, M.A.H. (1975) Influence of environment on blastocyst proliferation, differentiation and implantation. In Regulation of Growth and Differential Function in Eukaryote Cells, pp. 519-522. Ed. G. P. Talwar. Raven Press, New York.

Weitlauf, H.M. (1971) Influence of ovarian hormones on the incorporation of amino acids by blastocysts in vivo. In The Biology of the Blastocyst, pp. 277-290. Ed. R. J. Blandau. University of Chicago Press, Chicago.

Woodland, H.R. \& Graham, C.F. (1969) RNA synthesis during early development of the mouse. Nature, Lond. 221, 327.

Yoshinaga, K. \& Adams, C.E. (1966) Delayed implantation in the spayed, progesterone treated adult mouse. J. Reprod. Fert. 12, 593-595. 